\title{
Provenance of Cretaceous and Paleocene sandstones in the West Greenland basins based on detrital zircon dating
}

\author{
Anders Scherstén and Martin Sønderholm
}

The extensive and very deep ?Jurassic/Cretaceous-Palaeogene sedimentary basins offshore West Greenland have a significant petroleum exploration potential. This is particularly true for the offshore region west of Disko and Nuussuaq where a live petroleum system has been documented for many years. At present, stratigraphic knowledge in this area is almost nonexistent and analogue studies from onshore areas and offshore exploration wells to the south are therefore crucial to understanding the distribution and quality of possible reservoir rocks in the Disko-Nuussuaq offshore area.

One of the main risk parameters in petroleum exploration in this region is the presence of an adequate reservoir rock. Tectonostratigraphic considerations suggest that several sand-prone stratigraphic levels are probably present, but their provenance and reservoir quality are at present poorly known both onshore and offshore.

A sediment provenance study including zircon provenance $\mathrm{U}-\mathrm{Pb}$ dating and wholerock geochemical analysis was therefore initiated by the Geological Survey of Denmark and Greenland (GEUS) in preparation for the Disko West Licensing Round 2006 (Scherstén et al. 2007). The main aims of this study were to:

Fig. 1. Simplified geological map of eastern Canada and Greenland (modified from Escher \& Pulvertaft 1995 and St-Onge et al. 2006). Greenland is shown in a Paleocene pre-drift position (from Oakey 2005, p. 222). Arrows indicate possible source of Grenvillian age components in West Greenland zircon samples. Inset shows sampled localities in the Nuussuaq Basin; 1, Itsaku on Svartenhuk Halvø (SH); 2, Upernivik $\varnothing ; \mathbf{3}$, Ikorfat; 4, Paatuut; 5, Kingittoq; 6, Atanikerluk; 7, Pingu and $\mathbf{8}$, Grønne Ejland. Sampled wells are GRO\#3 (G), Hellefisk-1 and Qulleq-1.
1. Characterise the source areas and dispersal patterns for the various sandstone units of Cretaceous-Paleocene age in the Nuussuaq Basin and compare these with sandstone units in selected West Greenland offshore exploration wells (Figs 1, 2), employing advanced zircon provenance U-Pb dating using laser ablation inductively coupled plasma mass spectrometry (LA-ICP-MS; cf. Frei et al. 2006).

2. Detect possible changes in sediment source with time, e.g. local versus regional sources.

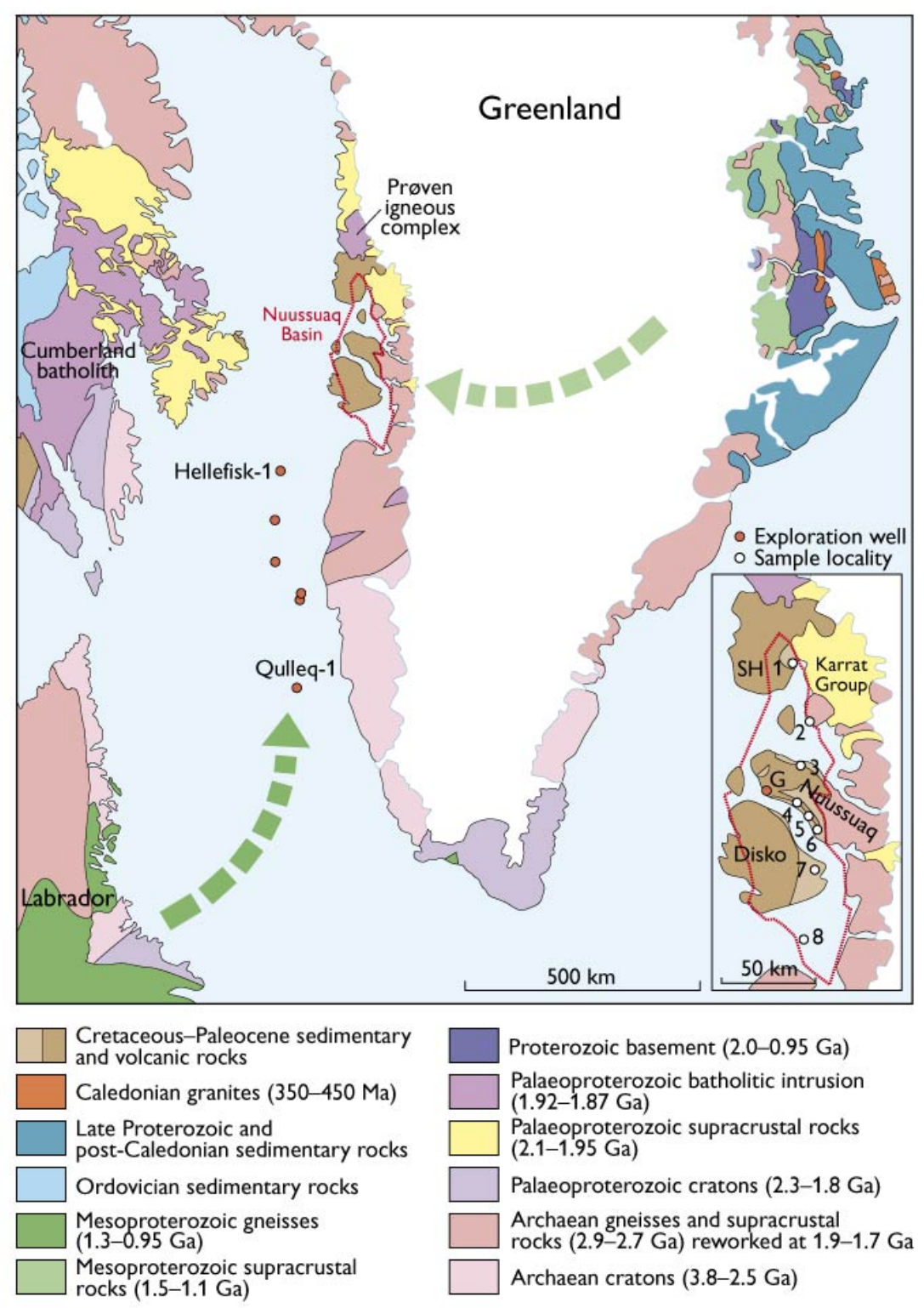




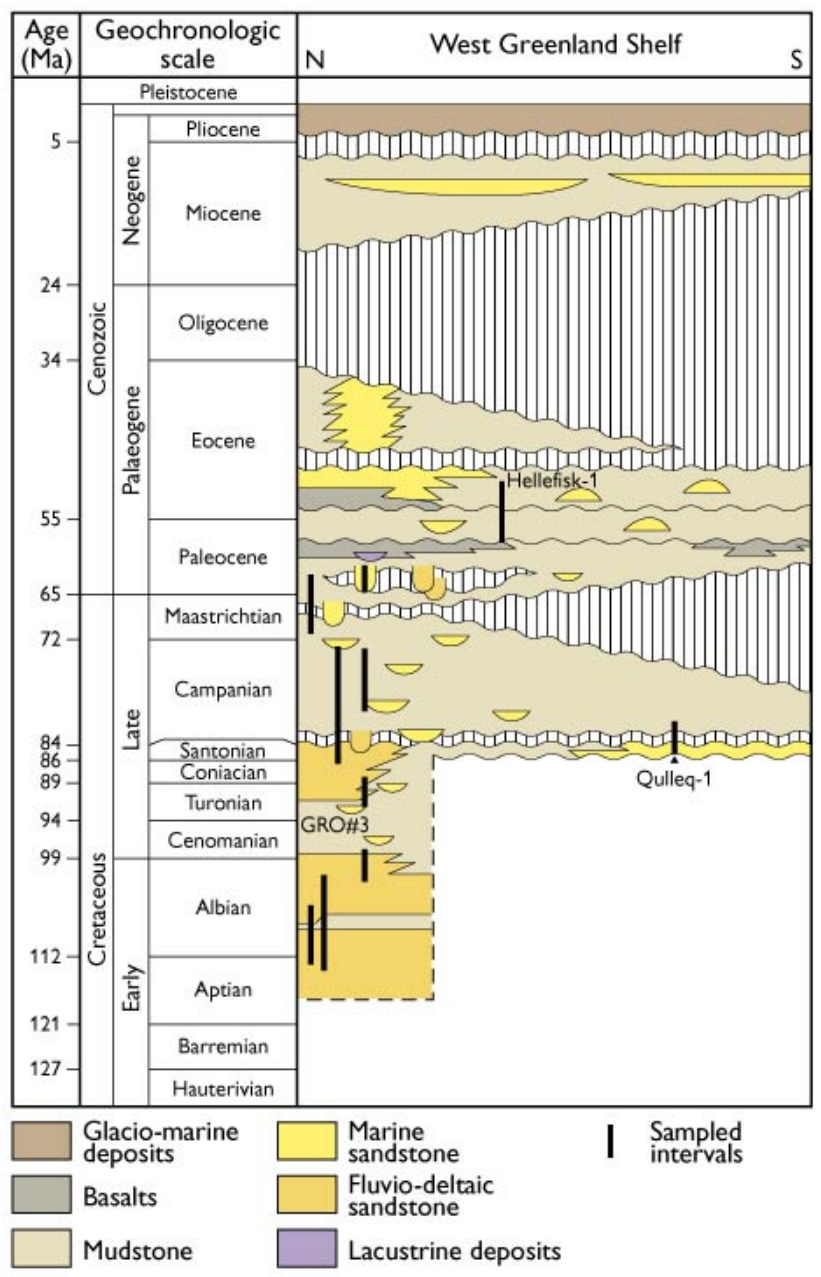

Fig. 2. Simplified stratigraphic scheme of the Nuussuaq Basin and West Greenland offshore region showing stratigraphic distribution of analysed samples.

Zircon as a provenance tool is receiving increasing attention and has proven to be a powerful indicator of clastic sediment sources, a tracer of the Earth's oldest materials, and a tracer of continental crust-forming processes (Froude et al. 1983; Williams \& Claesson 1987; Dodson et al. 1988; Fedo et al. 2003; Hawkesworth \& Kemp 2006). Zircon is common in continental rocks and it is assumed that its distribution in sediments will normally represent the source rocks. Although there are several complications, the sediment zircon $\mathrm{U}-\mathrm{Pb}$ age frequency should in general terms mirror the relative proportions of different source materials. This assumption is particularly important if exotic components can be identified, as their frequency will provide an estimate of the exotic influx: it may also be essential in tracing sediment paths that affect the detrital compositions and subsequent diagenetic history of possible hydrocarbon reservoir rocks.

\section{Cretaceous sediment provenance}

It is assumed that the age structure of the North Atlantic cratons surrounding the study area is well enough known to constrain the origin of the source components that contributed to the sediments. Archaean gneisses that range from 3850 to $2600 \mathrm{Ma}$ (Hollis et al. 2006) dominate southern West Greenland. Important peaks occur at 3600, 3100, 2900 and $2700 \mathrm{Ma}$. Farther north, the Archaean basement was reworked during the Nagssugtoqidian/Rinkian orogeny, which adds an age peak centred at 1900-1750 Ma (Figs 1, 3; Connelly et al. 2000).

As part of this study, 4262 grains were dated from 65 sediment samples from eight localities in the Nuussuaq Basin and three exploration wells (Fig. 1; Scherstén et al. 2007). Data that are $>10 \%$ discordant were filtered out as they are more likely to be disturbed by common $\mathrm{Pb}$ contamination, ancient Pb-loss and mixed domains. The remaining 2735 grains display a relative age distribution that is dominated by age peaks between $-2500-3200 \mathrm{Ma}$ (Fig. 3). There is also a peak at $-3600 \mathrm{Ma}$, which constitutes several samples suggesting that $3600 \mathrm{Ma}$ age components are perhaps more abundant than those from the well-known Godthåbsfjord area (Friend \& Nutman 2005; Hollis et al. 2006). A 1900

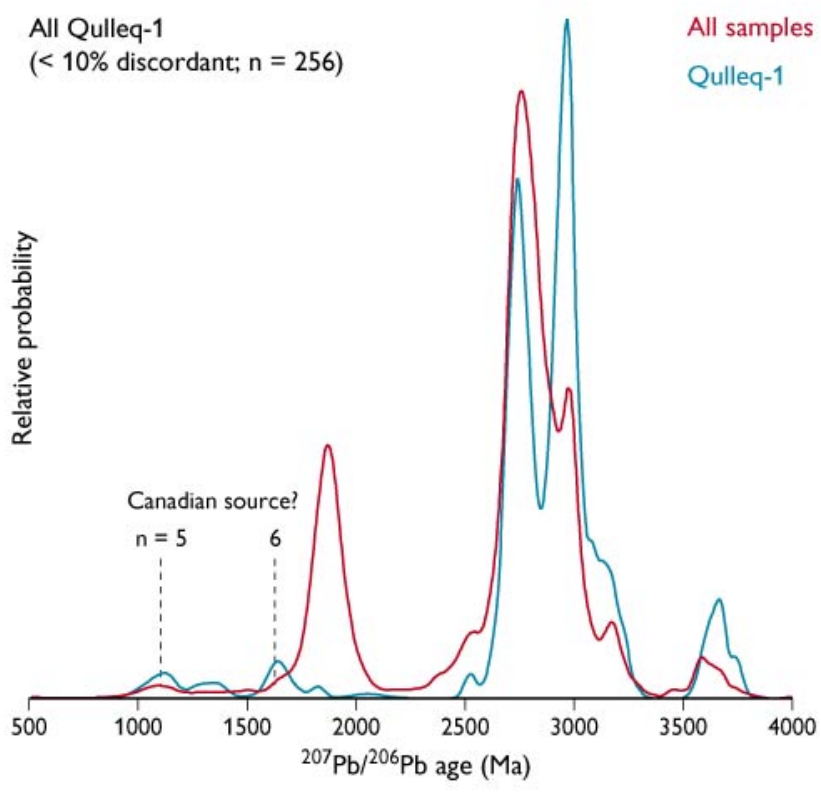

Fig. 3. Relative ${ }^{207} \mathrm{~Pb} /{ }^{206} \mathrm{~Pb}$ age distribution of $2735<10 \%$ discordant zircon grains from the Cretaceous-Palaeogene sediments in this study (red curve). The relative probability reflects the likelihood of finding any given age, although the $\sim 1900$ Ma peak is overrepresented due to sampling bias. Zircon ages from the Qulleq-1 well show small but significant peaks at $\sim 1600-1700$ and $\sim 1100 \mathrm{Ma}$ ( $\mathrm{n}$ is the number of grains that are within error of 1600 and $1100 \mathrm{Ma}$, respectively). These appear to be coupled and may have been either derived from East Greenland or the Canadian Shield. See text for further discussion. 
Ma peak is also distinct, but is probably overrepresented due to sampling bias through the many samples taken at Itsaku where this age component is strongly represented in comparison to the sediments farther south (see discussion below). The 1900 Ma peak is slightly asymmetric with a tail towards younger ages and an age component around 1600-1700 Ma. The overall age distribution is in excellent agreement with a source from the West Greenland crystalline basement; and the zircon data support the existing depositional models indicating that a major deltaic system drained into the Nuussuaq Basin from the east-south-east during Cretaceous-Paleocene time (Pedersen \& Pulvertaft 1992).

A small but significant peak at $\sim 1100$ Ma suggests a distal component that is not readily explained by derivation from the West Greenland crystalline basement as described above. This component seems to be associated with the 1600-1700 Ma occurrence noted above (Fig. 3). Two possible sources can explain the dual peaks: from East Greenland or Labrador (Fig. 1). If an East Greenland origin is favoured, it would be anticipated that this signature would also be associated with Caledonian ages between 380 and $480 \mathrm{Ma}$, which have not yet been identified (Figs 1, 3). Given the large number of grains analysed, it would be expected that even a very small contribution would have been detected suggesting Labrador as the most likely source for the $1100 \mathrm{Ma}$ peak. A southern, Labrador source for the $1100 \mathrm{Ma}$ component in the Qulleq-1 well is corroborated by the absence of the 1900 Ma peak that is ubiquitous in the Nuussuaq Basin to the north (Fig. 4). The samples from the Qulleq-1 well are dominated by Archaean ages without contributions from rocks reworked during the Nagssugtoqidian/Rinkian orogenic event.

In the Nuussuaq Basin the $1100 \mathrm{Ma}$ component is very rare in the onshore, deltaic facies and occurs almost exclusively in the deep-water deposits in accordance with a longshore transport component from the south as the source of this component. However, current data from turbidite channel units on western Nuussuaq show transport directions towards the south (Dam \& Sønderholm 1994). It is not possible to explain this apparent discrepancy based on the present database. More data including the other offshore wells will be needed to elucidate the possible interconnections and transport paths in the West Greenland offshore basins.

\section{Paleocene point source provenance on Svartenhuk Halvø}

A set of samples was collected on Itsaku on Svartenhuk Halvø where a major hiatus separates an Upper Albian to Lower Cenomanian deltaic succession from an Upper Campanian to Paleocene marine turbidite succession. The detrital zircon age

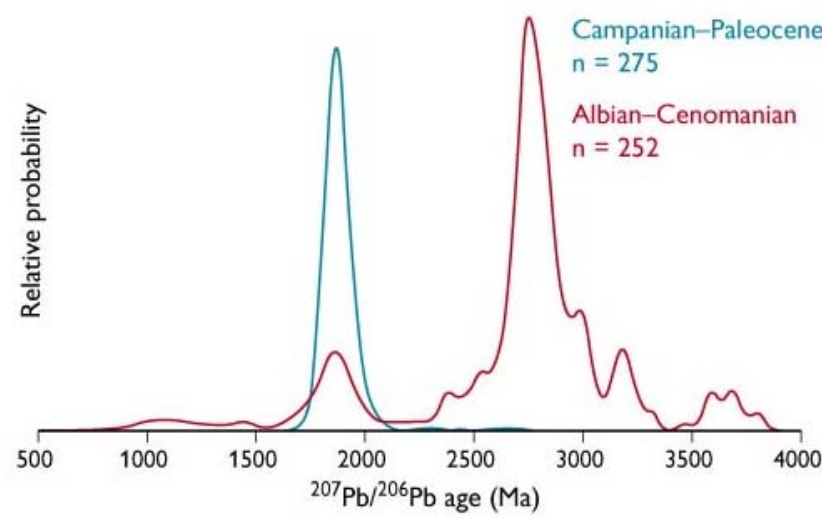

Fig. 4. Relative probability diagram for ${ }^{207} \mathrm{~Pb} /{ }^{206} \mathrm{~Pb}$ ages for zircon from Upper Albian - Cenomanian deltaic sediments (red) and Upper Campanian/Maastrichtian - Paleocene marine sediments (blue) on Itsaku, Svartenhuk Halvø. The deltaic deposits display a pattern that is typical for the sediments in the Nuussuaq Basin, whereas the constrained pattern of the overlying marine deposits is unique and seems to require a single point source.

distribution in the deltaic succession is typical for the Nuussuaq Basin and dominated by a distinct peak at -2800 $\mathrm{Ma}$; this is flanked by scattered peaks between 2400 and $3200 \mathrm{Ma}$ (Fig. 4), as well as significant peaks at 3600-3800 Ma representing Eoarchaean components. A 1900 Ma peak is another typical feature of the Nuussuaq Basin sediments, whereas the occurrences of 1100 and 1600-1700 Ma peaks are more intermittent (see above). The overall pattern is in good agreement with that of the general West Greenland Cretaceous population and deltaic deposition from the eastsouth-east.

The zircon age distribution of the overlying turbidite succession is in stark contrast to the lower section (Fig. 4). Here, the zircon population forms a single, well-defined $\sim 1900 \mathrm{Ma}$ peak with an apparent normal distribution indicative of a single point source with respect to zircon. The only known source that fits this distribution is the $1869 \pm 9 \mathrm{Ma}$ Prøven igneous complex (Fig. 1; Thrane et al. 2005). Assuming the Prøven igneous complex forms a single source to the upper part of the succession, a Tukey's biweight mean of $1872 \pm 4$ $\mathrm{Ma}(\mathrm{n}=275)$ can be calculated, which is in excellent agreement with the Prøven igneous complex. A few grains scatter towards $2700 \mathrm{Ma}$, which likely reflects inherited components, in accordance with its derivation from lower continental crust (Thrane et al. 2005).

Trace element systematics in zircon may provide further constraints on zircon origin in provenance studies (Hoskin $\&$ Ireland 2000). However, several hurdles need to be overcome. For instance, many features are shared intimately between zircon that are derived from widely different sources (Hoskin \& Ireland 2000), and in a detrital population each grain has 
to be treated separately, as a common age does not necessarily imply the same source rock, and by inference, the same crystallisation processes or conditions. Nevertheless, it is assumed here that zircon from the upper part of the section represents one population that was derived from the Prøven igneous complex. Trace element abundances were determined for 138 zircon grains from this part of the section and contrasted against Archaean $(\mathrm{n}=424)$ zircon grains from other stratigraphic levels. As expected, there are no systematic variations with age, which would require an age dependent systematic change in zircon crystallisation processes. Titanium in zircon thermometry (Watson et al. 2006) enables calculation of zircon crystallisation temperatures. The upper zircon population yields a mean temperature of $845 \pm 19^{\circ} \mathrm{C}$ $\left( \pm 2 \sigma_{\text {mean }} ; \mathrm{n}=93 ; \mathrm{GJ}-1\right.$ standard reproducibility $668 \pm 30^{\circ} \mathrm{C}$ $2 \sigma \mathrm{n}=17$ ), which is similar to zircon saturation temperatures of $790-880^{\circ} \mathrm{C}(\mathrm{n}=4)$ calculated from bulk rock data and the independently estimated intrusion temperature of the Prøven igneous complex (Thrane et al. 2005). The Prøven igneous complex is inferred to have been derived from a lower continental crust source as reflected by significantly negative Euanomalies from a plagioclase residue $\left(\mathrm{Eu} / \mathrm{Eu}^{*} \sim 0.45\right.$; Thrane et al. 2005). This appears to be reflected by the zircon population, which has a mean of $0.23 \pm 0.03\left( \pm 2 \sigma_{\text {mean }} ; \mathrm{n}=93\right.$; GJ-1 standard reproducibility $0.96 \pm 0.062 \sigma \mathrm{n}=23)$. The values contrast with the average Archaean population $\left(\mathrm{Eu} / \mathrm{Eu}^{*}=0.49 \pm 0.032 \sigma_{\text {mean }} ; \mathrm{n}=257\right)$, which is assumed to be dominated by rocks such as tonalite-trondhjemite-granodiorite (TTG) suites that have $\mathrm{Eu} / \mathrm{Eu}^{*} \sim 1.0$. Thus, the zircon population of the Upper Campanian to Paleocene marine turbidite succession seems to form a single population that is in accordance with derivation from the Prøven igneous complex. This implies a major change in depositional transport direction compared to the underlying Lower Cretaceous deltaic deposits from a south-eastern and eastern source to a northern source.

\section{Acknowledgement}

The project was supported by the Bureau of Minerals and Petroleum, Government of Greenland.

\section{References}

Connelly, J.N., van Gool, J.A.M. \& Mengel, F.C. 2000: Temporal evolution of a deeply eroded orogen: the Nagssugtoqidian Orogen, West Greenland. Canadian Journal of Earth Sciences 37, 1121-1142.
Dam, G. \& Sønderholm, M. 1994: Lowstand slope channels of the Itilli succession (Maastrichtian - lower Paleocene), Nuussuaq, West Greenland. Sedimentary Geology 94, 49-71.

Dodson, M.H., Compston, W., Williams, I.S. \& Wilson, J.F. 1988: A search for ancient detrital zircons in Zimbabwean sediments. Journal of the Geological Society (London) 145, 977-983.

Escher, J. \& Pulvertaft, T.C.R. 1995: Geological map of Greenland, $1: 2500$ 000. Copenhagen: Geological Survey of Greenland.

Fedo, C.M., Sircombe, K.N. \& Rainbird, R.H. 2003: Detrital zircon analysis of the sedimentary record. In: Hanchar, J.M. \& Hoskin, P.W.O. (eds): Zircon. Reviews in Mineralogy and Geochemistry 53, 277-303. Frei D., Hollis J.A., Gerdes A., Harlov D., Karlsson C., Vasquez P., Franz G., Johansson L. \& Knudsen, C. 2006: Advanced in-situ trace element and geochronological microanalysis of geomaterials by laser ablation techniques. Geological Survey of Denmark and Greenland Bulletin 10, 25-28.

Friend, C. \& Nutman, A. 2005: New pieces to the Archaean terrane jigsaw puzzle in the Nuuk region, southern West Greenland: steps in transforming a simple insight into a complex regional tectonothermal model. Journal of the Geological Society (London) 162, 147-162.

Froude, D.O., Ireland, T.R., Kinny, P.D., Williams, I.S., Compston, W., Williams, I.R. \& Myers, J.S. 1983: Ion microprobe identification of 4000-4200 Myr-old terrestrial zircons. Nature 304, 616-618.

Hawkesworth, C.J. \& Kemp, A.I.S. 2006: Evolution of the continental crust. Nature 443, 811-817.

Hollis, J.A., Frei, D., van Gool, J.A.M., Garde, A.A. \& Persson, M. 2006: Using zircon geochronology to resolve the Archaean geology of southern West Greenland. Geological Survey of Denmark and Greenland Bulletin 10, 49-52.

Hoskin, P.W.O. \& Ireland, T.R. 2000: Rare earth element chemistry of zircon and its use as a provenance indicator. Geology 28, 627-630.

Oakey, G.N. 2005: Cenozoic evolution and lithosphere dynamics of the Baffin Bay - Nares Strait region of Arctic Canada and Greenland, 233 pp. Amsterdam: Vrije Universiteit.

Pedersen, G.K. \& Pulvertaft, T.C.R. 1992: The nonmarine Cretaceous of the West Greenland Basin, onshore West Greenland. Cretaceous Research 13, 263-272.

Scherstén, A., Sønderholm, M. \& Steenfelt, A. 2007: Provenance of West Greenland Cretaceous and Paleocene sandstones and stream sediment samples based on U-Pb dating of detrital zircon: data and results. Danmarks og Grønlands Geologiske Undersøgelse Rapport 2007/21, 121 pp.

St-Onge, M. (compiler), van Gool, J.A.M., Garde, A.A. \& Scott, D.J. 2006: Correlations of Archaean to Mesoproterozoic units and structures across Baffin Bay, Davis Strait and the Labrador Sea: Kangerlussuaq workshop 2005 report and literature review. Danmarks og Grønlands Geologiske Undersøgelse Rapport 2006/6, 20-57.

Thrane, K., Baker, J., Connelly, J. \& Nutman, A. 2005: Age, petrogenesis and metamorphism of the syn-collisional Prøven igneous complex, West Greenland. Contributions to Mineralogy and Petrology 149, 541-555.

Watson, E.B., Wark, D.A. \& Thomas, J.B. 2006: Crystallisation thermometers for zircon and rutile. Contributions to Mineralogy and Petrology 151, 413-433.

Williams, I.S. \& Claesson, S. 1987: Isotopic evidence for the Precambrian provenance and Caledonian metamorphism of high grade paragneisses from the Seve Nappes, Scandinavian Caledonides: II. Ion microprobe zircon U-Th- $\mathrm{Pb}$. Contributions to Mineralogy and Petrology 97, 205-217. 